
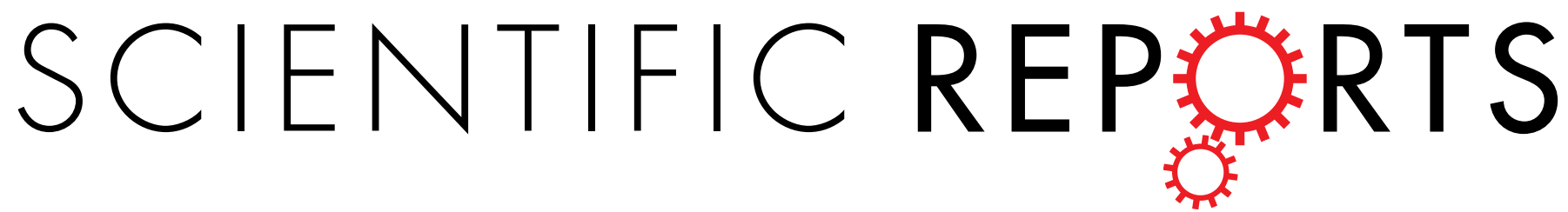

\title{
OPEN
}

Received: 2 May 2017

Accepted: 16 August 2017

Published online: 06 September 2017

\section{Halotolerant aminopeptidase M29 from Mesorhizobium SEMIA 3007 with biotechnological potential and its impact on biofilm synthesis}

\author{
Elwi Machado Sierra ${ }^{1,3}$, Mariana Rangel Pereira ${ }^{2}$, Thaís Carvalho Maester ${ }^{2}$, Elisangela Soares \\ Gomes-Pepe $\mathbb{D}^{1,2}$, Elkin Rodas Mendoza ${ }^{1}$ \& Eliana G. de Macedo Lemos ${ }^{1,2,4}$
}

The aminopeptidase gene from Mesorhizobium SEMIA3007 was cloned and overexpressed in Escherichia coli. The enzyme called MesoAmp exhibited optimum activity at $\mathrm{pH} 8.5$ and $45^{\circ} \mathrm{C}$ and was strongly activated by $\mathrm{Co}^{2+}$ and $\mathrm{Mn}^{2+}$. Under these reaction conditions, the enzyme displayed $\mathrm{K}_{\mathrm{m}}$ and $\mathrm{k}_{\text {cat }}$ values of $0.2364 \pm 0.018 \mathrm{mM}$ and $712.1 \pm 88.12 \mathrm{~s}^{-1}$, respectively. Additionally, the enzyme showed remarkable stability in organic solvents and was active at high concentrations of $\mathrm{NaCl}$, suggesting that the enzyme might be suitable for use in biotechnology. MesoAmp is responsible for $40 \%$ of the organism's aminopeptidase activity. However, the enzyme's absence does not affect bacterial growth in synthetic broth, although it interfered with biofilm synthesis and osmoregulation. To the best of our knowledge, this report describes the first detailed characterization of aminopeptidase from Mesorhizobium and suggests its importance in biofilm formation and osmotic stress tolerance. In summary, this work lays the foundation for potential biotechnological applications and/or the development of environmentally friendly technologies and describes the first solvent- and halo-tolerant aminopeptidases identified from the Mesorhizobium genus and its importance in bacterial metabolism.

A large diversity of Mesorhizobium species have been identified in different environmental niches, including artic soil ${ }^{1}$, marine sponge ${ }^{2}$, semi-arid and saline soil ${ }^{3}$, and polychlorinated biphenyl (PCB) contaminated soil ${ }^{4}$. The large distribution of Mesorhizobium sp. suggests that species within this genus have adapted to several eco-climatic conditions because of its heterogeneous and extremely plastic genome. Although knowledge of the role of Mesorhizobium in the nitrogen-fixing process is currently expanding, the potential for its use in biotechnology is still limited, because only a few biomolecules with industrial application have been reported. These enzymes with industrial applications include cyclic $\beta$ - $(1,2)$-glucans ${ }^{5}$, L-ribulose 3 -epimerase ${ }^{6}, \beta$-transaminase ${ }^{7}$, cellulase $^{8}$, L-rhamnose isomerase ${ }^{9}$ and pyridoxine 4 -oxidase ${ }^{10}$. However, despite the potential industrial relevance and a large database of peptidases [3179 known peptidases, and homologues from 29 Mesorhizobium genomes], there is almost no information concerning the biochemistry of the proteolytic system or any peptidase from the Mesorhizobium genus.

Aminopeptidases (EC 3.4.11) are a diverse group of exopeptidases involved in the catalysis of peptide bond cleavage at the amino-terminus of proteins, releasing amino acids residues, preferably hydrophobic ones. These enzymes are widely distributed in bacteria, fungi, plants and animal tissues with important physiological roles, such as the maturation and degradation of proteins, the regulation of hormonal levels, defence control, hydrolysis of regulatory peptides, regulation of genes expression, support of the amino acids pool ${ }^{11}$, peptidoglycane metabolism ${ }^{12}$, nitrogen nutrition and virulence factors ${ }^{13}$. Aminopeptidases are used extensively in the biopharmaceutical industry to remove $\mathrm{N}$-terminal sequences in the production of anti-hypertensive peptides ${ }^{11}$ and antiviral compounds ${ }^{14}$. Additionally, these enzymes have an important role in the food industry by modifying organoleptic characteristics (e.g., texture, bitterness and flavour) ${ }^{15}$. Furthermore, aminopeptidases can be used with other endopeptidases for wastewater treatment to degrade proteins ${ }^{16}$.

${ }^{1}$ Department of Technology, São Paulo State University, Jaboticabal, São Paulo State, Brazil. ${ }^{2}$ Institute for Research in Bioenergy (IPBEN), Jaboticabal, São Paulo State, Brazil. ${ }^{3}$ Universidad Simón Bolívar, Barranquilla, Colombia. ${ }^{4}$ Present address: Av. Prof. Paulo Donato Castellane, s/n. Jaboticabal, Post code 14884-900, São Paulo State, Brazil. Correspondence and requests for materials should be addressed to E.G.d.M.L. (email: egerle@fcav.unesp.br) 
Over the last years, several types of experiments to improve the physicochemical characteristics of these enzymes have been performed including chemical modification, protein immobilization, protein engineering and directed enzyme evolution. However, if the enzymes are naturally stable and exhibit high activities in the presence of physicochemical factors, such modifications are not necessary. Therefore, it is conceivable that genomic data mining could be used to find an enzyme naturally stable or catalytically efficient enough to optimally fit process requirements that are solely dictated by substrate and product properties. In the era of big data, the genomic resources in various databases are highly valuable, making genomic data mining a growing area with an unprecedented capacity for the discovery of novel enzymes, since a huge abundance of enzymes already exists in these unexplored genomic resources.

In this study, we report the discovery of the mesoamp gene by genomic data mining. The gene shares $54 \%$ sequence identity with aminopeptidase T from Thermus thermophilus when analysed with The Peptidase Database (MEROPS). This gene was cloned into an expression vector and the recombinant protein, named MesoAmp, was functionally and physically characterized. Our results show that MesoAmp could be overexpressed in a stable dimeric form and purified without contaminants. The functional characterization of the enzyme showed that it was active in the presence of a high concentration of salt and organic solvents. Taken together, these data demonstrate the interesting features of MesoAmp in bacterial metabolism and support the potential of this enzyme for use in biotechnological processes.

\section{Results}

Sixty-eight peptidases were predicted by comparative genomic analysis. The automatic annotation tool identified 101 ORFs that possibly encode peptidases that are similar to the Mesorhizobium genome annotated in MEROPS ${ }^{17}$. To characterize the proteolytic machinery of the Mesorhizobium genus, the protein sequences of each of the 101 ORFs were subjected to an exhaustive search against the MEROPS peptidase database. Using the comparative database search, we detected a total of sixty-eight peptidases belonging to 26 clans of proteolytic enzymes. These enzymes were distributed into groups based on the catalytic type of the proteolytic mechanism: $6.8 \%$ aspartic, $3 \%$ glutamic, $2.7 \%$ cysteine, $41.1 \%$ metallo, $35.6 \%$ serine, $4.1 \%$ treonin, $4.1 \%$ mixed and 5.5\% peptidase inhibitors (Table S2). This finding supports our hypothesis that a large number of peptidases with biotechnological potential remain unexplored in the Mesorhizobium genome.

Three peptidases with biotechnological potential were discovered. Considering the physicochemical characteristics of peptidases with similar sequences and biochemical characteristics as $\mathrm{pH}$, temperature and thermostability, we identified three enzymes with potential biotechnological applications (Table S3).

We selected Aminopeptidase $\mathrm{T}$ and called the enzyme MesoAmp. We focused on this enzyme for further bioinformatic analysis and biochemical characterization.

Sequence analysis of MesoAmp revealed the amino acid fingerprint of thermophilic metalloproteases. The sequence of MesoAmp consists of $1257 \mathrm{pb}(\mathrm{G}+\mathrm{C}$ content $=64 \%)$ encoding a protein with 418 amino acids. No signal peptide sequence was identified. The comparison of the complete amino acid sequence with the proteins from the database displayed the highest homology (95\%) with the aminopeptidase from Mesorhizobium ciceri and another species of Mesorhizobium. MesoAmp has $54 \%$ sequence identity with an aminopeptidase T (AmpT) from Thermus thermophilus (MER001285), 40\% sequence identity with aminopeptidase S (PepS) (MER005731) and the aminopeptidase S (AmpS) (MER014416) enzymes from Streptococcus thermophilus and Staphylococcus aureus, respectively.

The multiple sequence alignment of the MesoAmp sequence with AmpT, PepS and AmpS revealed an 8 amino acid fingerprint that provides a signature for a thermophilic metalloprotease ${ }^{18}$, as well as the catalytic amino acid Tyr at position 352 and the metal-binding residues Glu259, Glu325, His354, His387 that are shown in detail in Supplementary Figure S1. The analysis using the ConSurf server revealed that the most conserved amino acids located in the C-terminus of the protein (Supplementary Figure S1).

Dimeric structure of MesoAmp with high degree of conservation. The three-dimensional model of MesoAmp was created using Modeller and validated using ModFold that demonstrated that there was less than a 1:1,000 chance that the models were incorrect. The Ramachandran plots for the models revealed a relatively high number of amino acids in allowed regions (98.08\%) that is an indication for further model optimizations. The structural model of MesoAmp superimposed remarkably well with the AmpS structure, displaying a r.m.s.d of $0.508 \AA$ (Fig. 1A and B). The analysis using Z-Dock revealed a homodimer structure with an N-terminal dimerization domain (Fig. 1C). The conserved residues between scarcely conserved clusters located on the surface of the protein (Fig. 1D) are presumably important for the maintenance of the structural integrity of these surface patches ${ }^{19}$. Buried inside the protein is the highly conserved region constituting the substrate-binding pocket (Fig. $1 \mathrm{D}$ and E) and the substrate-binding cavity of $1,780 \AA^{3}$ (Fig. $1 \mathrm{~F}$ ).

MesoAmp was expressed in the soluble fraction and the active enzyme obtained was in a dimeric form. The optimal conditions for the production of the soluble and active form of MesoAmp from $E$. coli BL21(DE3) were IPTG at a final concentration of $0.1 \mathrm{mM}$, an induction temperature of $30^{\circ} \mathrm{C}$ and $12 \mathrm{~h}$ growth under $200 \mathrm{rpm}$. Under these conditions, the recombinant protein was soluble in the supernatant of the cell lysate that aided further purification. The SDS-PAGE analysis of purified MesoAmp revealed the enzyme was completely purified by affinity chromatography and weighed $45.72 \mathrm{kDa}$ under denaturing conditions (Supplementary Figure S2A) as predicted with ProtParam tool (http://us.expasy.org/tools/protparam.html). The molecular mass of the native enzyme was estimated to be $88.05 \mathrm{kDa}$ by gel filtration (Supplementary Figure S2B). Our results indicate that the enzyme is a homodimer that is highly common for the aminopeptidase M29 family ${ }^{20}$. 
A

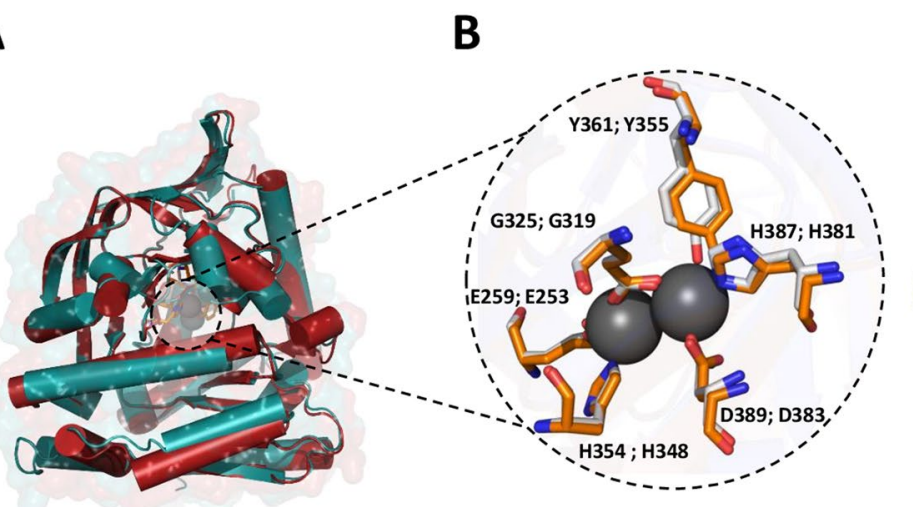

C

r.m.s.d $=0.508$

$\mathbf{E}$
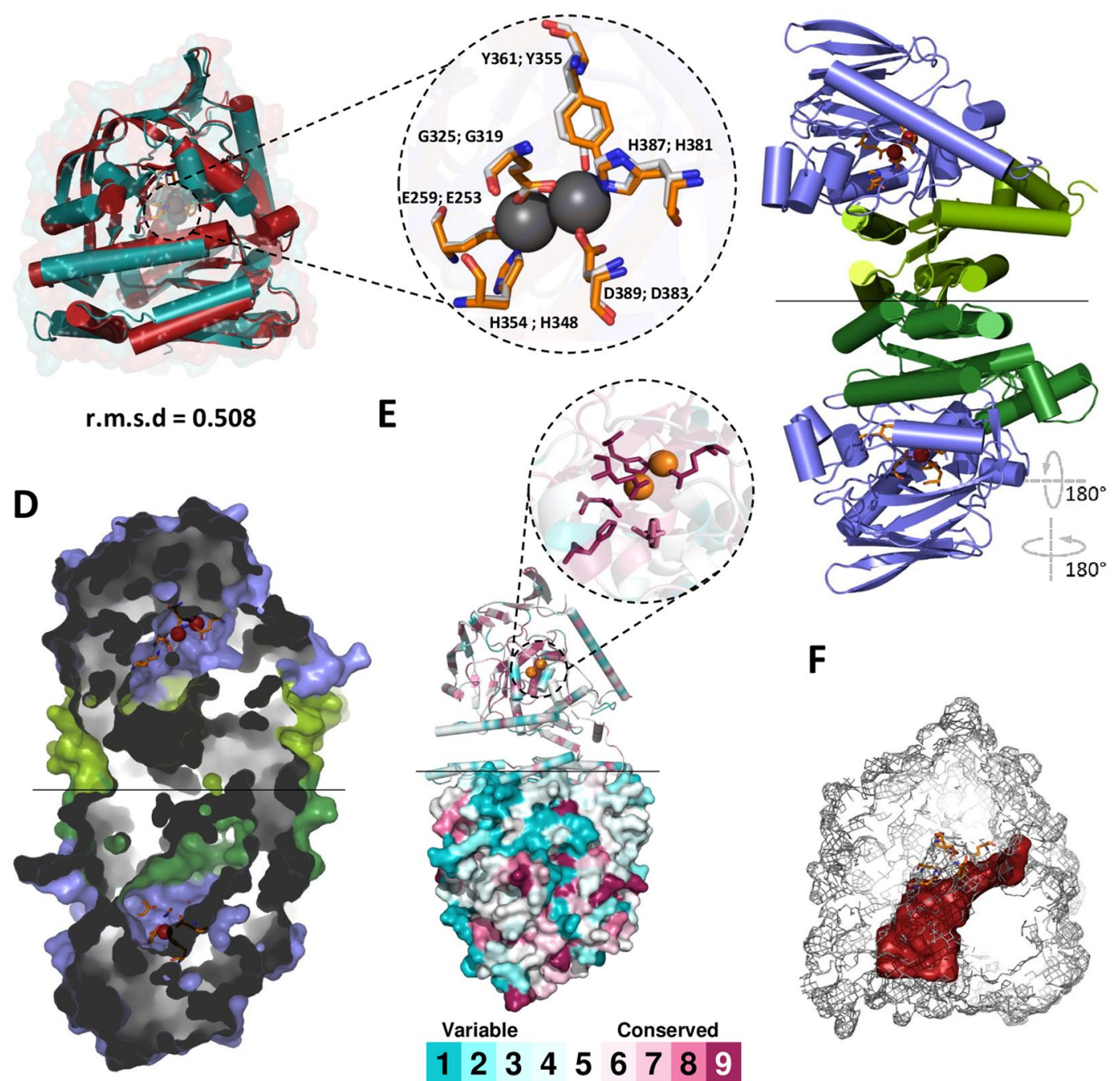

$\mathbf{F}$

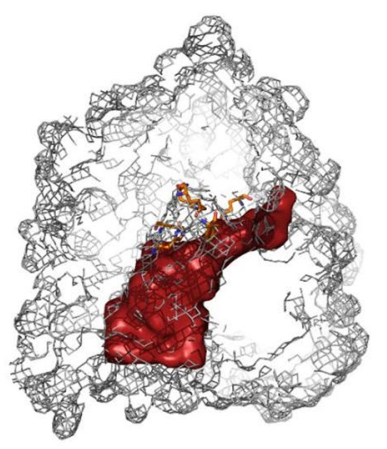

Figure 1. The structural features of the MesoAmp model. (A) The superimposed structures of MesoAmp model (gray) with the structure of Staphylococcus aureus aminopeptidase chain A (blue), revealing the conservation of the alpha/beta fold, with a root mean square deviation (r.m.s.d) of $0.582 \AA$. The metal atoms are shown as gray spheres. (B) The superimposition of the catalytic residue (Tyr 361) and the metal-binding residues Glu259, Glu325, His354, His387 and Asp389, and their counterpart residues in the AmpS structure and the cobalt atoms are shown as gray spheres. (C) A cartoon structure of the dimeric arrangement of MesoAmp with its N-terminal domain involved in dimerization shown in green and its C-terminal domain (catalytic region) shown in blue. (D) Modelling representation of the substrate-binding site of MesoAmp homodimer using the code-color conservation of Consurf server. (E) The mesh representation of the substrate-binding hole (gray) and binding pocket (red) with substrate Trp-Gly (WG). r.s.m.d = root-mean-square deviation.

MesoAmp is active in a wide range of $\mathrm{pH}$ values and temperatures. The effects of $\mathrm{pH}$ and temperature on MesoAmp activity were examined spectrophotometrically using Leu-p-NA as substrate. The $\mathrm{pH}$ curve displayed a maximum activity within a narrow $\mathrm{pH}$ range from $\mathrm{pH} 7.5$ to 9.0 with no significant difference between these $\mathrm{pH}$ values (Fig. 2A). The enzymatic activity was almost completely lost when the $\mathrm{pH}$ was lower than 6.5 or higher than 10.0. The experiments subsequently described were carried out in $100 \mathrm{mM}$ bicarbonate sodium-hydroxide buffer at $\mathrm{pH}$ 8.5. The purified recombinant MesoAmp exhibited the highest activity at $40^{\circ} \mathrm{C}$. Interestingly, MesoAmp still maintained more than $80 \%$ of its activity in the temperature range from 35 to $55^{\circ} \mathrm{C}$ (Fig. 2B).

The CD spectrum of the recombinant protein displayed two negative peaks in the far-UV region at $208 \mathrm{~nm}$ and $222 \mathrm{~nm}$, as expected for alpha-beta secondary structure (Supplementary Figure S3A). MesoAmp displayed a melting temperature $\left(\mathrm{T}_{\mathrm{m}}\right)$ of $53.2^{\circ} \mathrm{C}$ in the presence and absence of $\mathrm{Co}^{2+}$ ions. Therefore, the cobalt ion does not change the alpha-beta content in the thermal denaturation assay (data not shown). Temperatures above $40^{\circ} \mathrm{C}$ induced the denaturation of the $\alpha$-helical structure of MesoAmp, showing a transition to the irreversible state (Supplementary Figure S3B). The disruption of its secondary structure begins below $55^{\circ} \mathrm{C}$ as indicated by the 
A

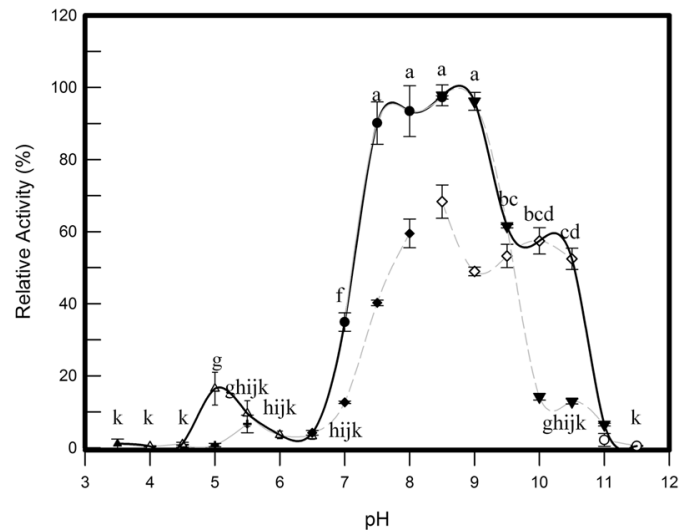

B

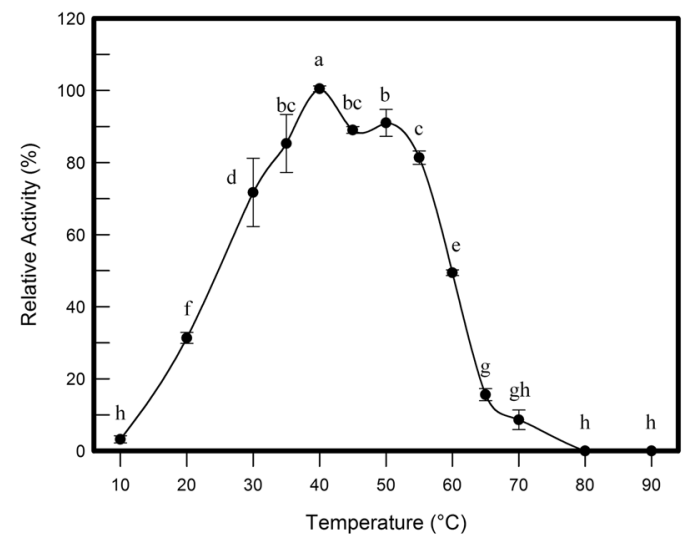

Figure 2. Physicochemical analysis of MesoAmp. (A) The $\mathrm{pH}$ effect on the enzymatic activity of MesoAmp in different buffers: McIlvaine buffer $(\boldsymbol{\Lambda})$; Sodium citrate buffer $(\Delta)$; Sodium phosphate buffer $(\diamond)$; Tris- $\mathrm{HCl}$ buffer $(\bullet)$; Bicarbonate-Sodium hydroxide buffer $\mathbf{\nabla})$; Glycine-sodium hydroxide buffer $(\diamond)$ and Monosodium phosphate - Sodium hydroxide buffer (O). (B) The temperature effect on MesoAmp activity determined in 100 $\mathrm{mM}$ Bicarbonate-Sodium hydroxide buffer ( $\mathrm{pH}$ 8.5). The data are expressed as Mean $\pm \mathrm{SD}$ of five independent experiments.

\begin{tabular}{|c|c|c|c|}
\hline \multirow{2}{*}{$\begin{array}{l}\text { Metal ion } \\
\text { None }\end{array}$} & & \multicolumn{2}{|c|}{ relative activity (\%) } \\
\hline & & 100 & ghij \\
\hline $\mathrm{Al}^{2+}$ & & $5.43 \pm 0.84$ & $\mathrm{k}$ \\
\hline $\mathrm{Ba}^{2+}$ & & $19.50 \pm 0.97$ & $\mathrm{ijk}$ \\
\hline $\mathrm{Ca}^{2+}$ & & $7.36 \pm 0.71$ & $\mathrm{k}$ \\
\hline $\mathrm{Cd}^{2+}$ & & $13.93 \pm 2.76$ & jk \\
\hline $\mathrm{Mg}^{2+}$ & & $152.07 \pm 5.28$ & gh \\
\hline $\mathrm{Zn}^{2+}$ & & $11.29 \pm 2.64$ & $\mathrm{jk}$ \\
\hline $\mathrm{Cu}^{2+}$ & & $65.21 \pm 9.81$ & hijk \\
\hline $\mathrm{I}^{2+}$ & & $108.50 \pm 6.37$ & ghi \\
\hline $\mathrm{Li}^{2+}$ & & $76.78 \pm 3.48$ & hijk \\
\hline $\mathrm{Ni}^{2+}$ & & $179.00 \pm 6.29$ & $\mathrm{fg}$ \\
\hline \multicolumn{4}{|l|}{$\mathrm{Mn}^{2+}$} \\
\hline & $1 \mathrm{mM}$ & $844.01 \pm 77.52$ & $\mathrm{c}$ \\
\hline & $2 \mathrm{mM}$ & $284.29 \pm 26.63$ & $\mathrm{e}$ \\
\hline & $3 \mathrm{mM}$ & $295.93 \pm 49.85$ & $\mathrm{e}$ \\
\hline & $4 \mathrm{mM}$ & $334.36 \pm 26.71$ & $\mathrm{e}$ \\
\hline & $5 \mathrm{mM}$ & $473.02 \pm 41.11$ & $\mathrm{~d}$ \\
\hline \multicolumn{4}{|l|}{$\mathrm{Co}^{2+}$} \\
\hline & $1 \mathrm{mM}$ & $51.36 \pm 13.95$ & $\mathrm{ijk}$ \\
\hline & $2 \mathrm{mM}$ & $412.86 \pm 63.63$ & $\mathrm{~d}$ \\
\hline & $3 \mathrm{mM}$ & $1460.93 \pm 88.51$ & $\mathrm{~b}$ \\
\hline & $4 \mathrm{mM}$ & $1768.09 \pm 133.65$ & $\mathrm{a}$ \\
\hline & $5 \mathrm{mM}$ & $1597.07 \pm 59.58$ & $\mathrm{~b}$ \\
\hline
\end{tabular}

Table 1. The effect of various divalent cations on the MesoAmp activity. The small letters on the right of the values $(a, b, c, \ldots k)$ indicates the significant difference between each condition tested in the experiment, according to an ANOVA and Tukey's test at 5\% probability. The data are expressed as Mean $\pm \mathrm{SD}$ of seven independent experiments.

increase in the unfolded fraction (60\% unfolded), whereas the enzymatic activity is not significantly altered up to this point.

Metallopeptidases exhibit a broad range of metal-ion dependencies. The activity of MesoAmp in the presence of different metal ions is shown in Table 1 . Approximately $90 \%$ of the activity was lost in the presence of $\mathrm{Ca}^{2+}$, $\mathrm{Ba}^{2+}, \mathrm{Al}^{2+}$ and $\mathrm{Zn}^{2+}$ ions. Conversely, MesoAmp displayed enhanced catalytic activity in the presence of $\mathrm{Co}^{2+}$ and $\mathrm{Mn}^{2+}$ ions (17-fold and 8-fold, respectively). All other metal ions tested (with a rank order of $\mathrm{Mg}^{2+}>\mathrm{Ni}^{2+}>$ $\mathrm{Mg}^{2+}>\mathrm{I}^{2+}$ ) had stimulatory effects on the enzymatic activity of MesoAmp. 


\begin{tabular}{|c|c|c|c|}
\hline \multicolumn{2}{|l|}{ Inhibitors } & \multicolumn{2}{|c|}{ Relative activity (\%) } \\
\hline None & & 100 & $\mathrm{bc}$ \\
\hline \multicolumn{4}{|l|}{ EDTA } \\
\hline & $5 \mathrm{mM}$ & $48.76 \pm 3.39$ & ij \\
\hline & $10 \mathrm{mM}$ & $32.29 \pm 0.56$ & $\mathrm{kl}$ \\
\hline & $20 \mathrm{mM}$ & $18.41 \pm 0.76$ & $\mathrm{mn}$ \\
\hline PMSF $10 \mathrm{mM}$ & & $96.89 \pm 1.75$ & $\mathrm{bc}$ \\
\hline Iodoacetic acid $10 \mathrm{mM}$ & & $97.93 \pm 2.89$ & $\mathrm{bc}$ \\
\hline \multicolumn{2}{|l|}{ Denaturant agent } & \multicolumn{2}{|c|}{ Relative activity (\%) } \\
\hline None & & 100 & $\mathrm{bc}$ \\
\hline \multicolumn{4}{|l|}{$\beta$-Mercaptoethanol } \\
\hline & $1 \mathrm{mM}$ & $80.16 \pm 4.18$ & de \\
\hline & $5 \mathrm{mM}$ & $61.67 \pm 1.22$ & jk \\
\hline & $10 \mathrm{mM}$ & $32.29 \pm 0.56$ & $\operatorname{lm}$ \\
\hline \multicolumn{4}{|l|}{ DTT } \\
\hline & $1 \mathrm{mM}$ & $10.07 \pm 0.93$ & no \\
\hline & $5 \mathrm{mM}$ & $2.12 \pm 0.07$ & o \\
\hline & $10 \mathrm{mM}$ & $1.41 \pm 0.06$ & o \\
\hline \multicolumn{4}{|l|}{ Guanidine- $\mathrm{HCl}$} \\
\hline & $0.5 \mathrm{M}$ & $67.78 \pm 0.40$ & $\mathrm{fg}$ \\
\hline & $1 \mathrm{M}$ & $29.10 \pm 1.11$ & $\operatorname{lm}$ \\
\hline & $2 \mathrm{M}$ & $3.50 \pm 0.34$ & o \\
\hline \multicolumn{4}{|l|}{ Urea } \\
\hline & $0.5 \mathrm{M}$ & $92.65 \pm 7.78$ & $\mathrm{bc}$ \\
\hline & $1 \mathrm{M}$ & $73.36 \pm 6.25$ & ef \\
\hline & $2 \mathrm{M}$ & $54.11 \pm 3.27$ & hi \\
\hline \multicolumn{4}{|l|}{$\mathrm{NaCl}$} \\
\hline & $0.5 \mathrm{M}$ & $127.31 \pm 9.11$ & $\mathrm{a}$ \\
\hline & $1 \mathrm{M}$ & $125.94 \pm 3.49$ & a \\
\hline & $2 \mathrm{M}$ & $121.81 \pm 0.16$ & $\mathrm{a}$ \\
\hline & $3 \mathrm{M}$ & $103.45 \pm 2.76$ & $\mathrm{bc}$ \\
\hline & $4 \mathrm{M}$ & $87.54 \pm 1.56$ & ef \\
\hline
\end{tabular}

Table 2. The effect of inhibitors and denaturing agents on the activity of MesoAmp*. *Enzyme assays were performed in $100 \mathrm{mM}$ Bicarbonate-Sodium hydroxide buffer at $\mathrm{pH} 8.5$ and $40^{\circ} \mathrm{C}$. The small letters on the right of the values $(a, b, c, \ldots m)$ indicates the significant difference between each condition tested in the experiment, according to an ANOVA and Tukey's test at $5 \%$ probability. The data are expressed as Mean \pm SD of seven independent experiments.

After determining the optimum temperature and $\mathrm{pH}$, the activity of MesoAmp was tested with Leu-p-NA at $\mathrm{pH} 8.5,40^{\circ} \mathrm{C}$ in the presence of $3 \mathrm{mM} \mathrm{Co}^{2+}$. The $\mathrm{K}_{\mathrm{m}}, \mathrm{V}_{\max }$ and $\mathrm{K}_{\text {cat }}$ values were calculated to be $0.2364 \pm 0.0182$ $\mathrm{mM}, 1.115 \pm 0.020 \mathrm{mM} . \mathrm{s}^{-1}$ and $712.1 \pm 88.12 \mathrm{~s}^{-1}$ respectively.

Thermal treatment at 45 and $50^{\circ} \mathrm{C}$ after 60 min pre-incubation did not influence the activity of the enzyme. However, MesoAmp lost half of its activity when incubated at $55^{\circ} \mathrm{C}$ for $15 \mathrm{~min}$, and it was rapidly inactivated when incubated at $70^{\circ} \mathrm{C}$ (Supplementary Figure S4). After 5 min incubations at these higher temperatures, the enzymatic activity decreased by approximately $95 \%$.

MesoAmp retains its activity in the presence of organic solvents and at high salt concentrations. PMSF and iodoacetic acid did not influence enzyme activity. However, metal-chelating agents such as EDTA severely inhibited its activity (Table 2) indicating that MesoAmp is a metallopeptidase. We tested the activity of the enzyme in the presence of denaturing agents (Table 2). The MesoAmp activity was very sensitive to concentrations of guanidine- $\mathrm{HCl}$ between 0.5 and $2.0 \mathrm{M}$, indicating a significant disruption in the secondary structure of the protein. However, urea treatment did not substantially affect the activity at concentrations of 0.5 $\mathrm{M}$ and $1 \mathrm{M}$ but reduced the activity by half when at $2 \mathrm{M}$.

Zhuo and Dixon ${ }^{21}$ found that the role of sulfhydryl reagents was to chelate small amounts of metal ions. To prevent this chelating mechanism, we measured the enzymatic activity without metal ions. The role of DTT as a metal chelator makes it unsuitable to use with MesoAmp. As shown in Table 2, the presence of DTT and $\beta$-mercaptoethanol considerably decreased the enzymatic activity. On the other hand, $\mathrm{NaCl}$ treatment enhanced the activity of MesoAmp (Table 2) by 1.2-fold compared to the enzymatic activity without $\mathrm{NaCl}$.

The presence of non-ionic surfactants, such as Tween (20 and 80) and Triton (X-100 and X-114), slightly decreased the amount of enzymatic activity (Table 3 ). Nevertheless, ionic and cationic surfactants (SDS and $\mathrm{CTAB}$ ) resulted in complete loss of MesoAmp activity (data not shown). Previous reports have indicated that 


\begin{tabular}{|c|c|c|c|}
\hline \multicolumn{2}{|c|}{ Detergents } & \multicolumn{2}{|c|}{ Relative Activity (\%) } \\
\hline None & & 100 & $\mathrm{bc}$ \\
\hline \multicolumn{4}{|c|}{ Triton X100 } \\
\hline & $0.5 \%$ & $76,81 \pm 3,236$ & fghi \\
\hline & $1 \%$ & $73,74 \pm 5,970$ & ghi \\
\hline & $2 \%$ & $70,15 \pm 1,688$ & i \\
\hline \multicolumn{4}{|c|}{ Triton X114 } \\
\hline & $0.5 \%$ & $81,64 \pm 4,532$ & efgh \\
\hline & $1 \%$ & $75,89 \pm 4,341$ & fghi \\
\hline & $2 \%$ & $83,47 \pm 1,751$ & defg \\
\hline \multicolumn{4}{|c|}{ Tween 20} \\
\hline & $0.5 \%$ & $73,77 \pm 1,840$ & ghi \\
\hline & $1 \%$ & $71,20 \pm 2,962$ & hi \\
\hline & $2 \%$ & $69,54 \pm 2,090$ & i \\
\hline \multicolumn{4}{|c|}{ Tween 80} \\
\hline & $0.5 \%$ & $77,24 \pm 3,491$ & fghi \\
\hline & $1 \%$ & $84,43 \pm 5,220$ & defg \\
\hline & $2 \%$ & $90,25 \pm 2,714$ & cde \\
\hline
\end{tabular}

Table 3. The effect of various detergents on the activity of MesoAmp*. *Enzyme assays were performed in $100 \mathrm{mM}$ Bicarbonate-Sodium hydroxide buffer at $\mathrm{pH} 8.5$ and $40^{\circ} \mathrm{C}$. The small letters on the right of the values $(a, b, c, \ldots i)$ indicates the significant difference between each condition tested in the experiment, according to an ANOVA and Tukey's test at 5\% probability. The data are expressed as Mean \pm SD of seven independent experiments.

the inhibitory effect of SDS or CTAB could be caused by their binding to the enzyme at more than one site, thus modifying the tertiary structure and altering the charge distribution ${ }^{20}$.

One of the most interesting characteristics of MesoAmp is its stability in the presence of organic solvents, as shown in Fig. 3. Interestingly, the activity of MesoAmp was stable, particularly at $5 \%$ and $10 \%(\mathrm{v} / \mathrm{v})$ concentrations of ethanol, methanol, 2-propanol and hexane, with a slight increase in activity at $20 \%(\mathrm{v} / \mathrm{v})$ ethanol and methanol. However, at $40 \%(\mathrm{v} / \mathrm{v})$, the enzyme was completely inactivated. In the presence of acetone, DMSO, chloroform, butanol and heptane at concentrations above $10 \%$, the enzymatic activity decreased by $50 \%$ followed by complete inactivation at higher concentrations of these solvents.

MesoAmp is not required for growth in vitro but is necessary for biofilm production and halotolerance. MesoAmp was responsible for $40 \%$ of the intracellular leucine aminopeptidase activity (Fig. 4A). Nevertheless, both strains Mesorhizobium SEMIA3007 and $\Delta$ mesoamp did not display a significant difference of growth in TY broth (Fig. 4B) suggesting that MesoAmp is not involved in growth in synthetic media. To determine the potential role of peptidases in Mesorhizobium SEMIA3007 metabolism, the halo-tolerance, solvent-tolerance and biofilm production of the $\Delta$ MesoAmp mutant was evaluated.

Biofilm formation is an important microbial survival strategy. We therefore examined whether the absence of the MesoAmp enzyme had an effect on biofilm formation in Mesorhizobium SEMIA3007. Figure 5A reveals a significant decrease (80\%) in the capacity in biofilm formation in PGE broth (glucose as carbon source) and $50 \%$ in PGY broth (glycerol as carbon source) for $\Delta$ mesoamp. The effect of mesoamp gene expression on Mesorhizobium stress tolerance was studied by liquid culture assays. When assayed by the liquid culture method under saline stress conditions, growth of $\Delta$ mesoamp cells decreased significantly with time compared to Mesorhizobium SEMIA3007 strain (Fig. 5B). $\Delta$ mesoamp displayed approximately 60 to $80 \%$ decreased saline stress tolerance in 0.2 and $0.3 \mathrm{M}$ of NaCl , respectively, and a total loss of tolerance to higher concentrations of salt $(0.4$ and $0.5 \mathrm{M}$, respectively). Mesorhizobium SEMIA3007 and $\Delta$ mesoamp showed tolerance to DMSO and hexane (Figure S5). According to the literature, the mechanisms by which bacteria present solvent tolerance (adaptations such as the efflux pumps, cis-trans fatty acids membrane isomerisation, rapid membrane repair mechanisms and membrane-localized transporters ${ }^{22,23}$ ) are several and complexes, thus cannot be attributed to a single gene.

\section{Discussion}

To date, in addition to the genes observed in bacteria, the ones encoding M29 aminopeptidases have been identified in animals, plants and Archea. However, a highly limited number of aminopeptidases M29 from Thermus aquaticus, Thermus thermophilus, Bacillus stearothermophilus, Streptococcus thermophilus, S. pneumoniae, S. aureus, Borrelia burgdorferi and Listeria monocitogenes have been characterized ${ }^{13,20,24,25}$. In this study, we present the results of genomic data mining in Mesorhizobium sp., as well as the cloning, overproduction in E. coli, and characterization of a highly halo-tolerant and solvent-tolerant aminopeptidase. This is a promising enzyme with possible applications in the production of debittered hydrolysates, the conversion of L-homophenylalanyl amide into L-homophenylalanine, and the development of flavouring for dairy products ${ }^{20}$.

The protein encoded by the mesoamp gene possesses only $40 \%-50 \%$ sequence identity with other members of the M29 family of characterized metallopeptidases. It displays a conserved catalytic domain in the C-terminal 

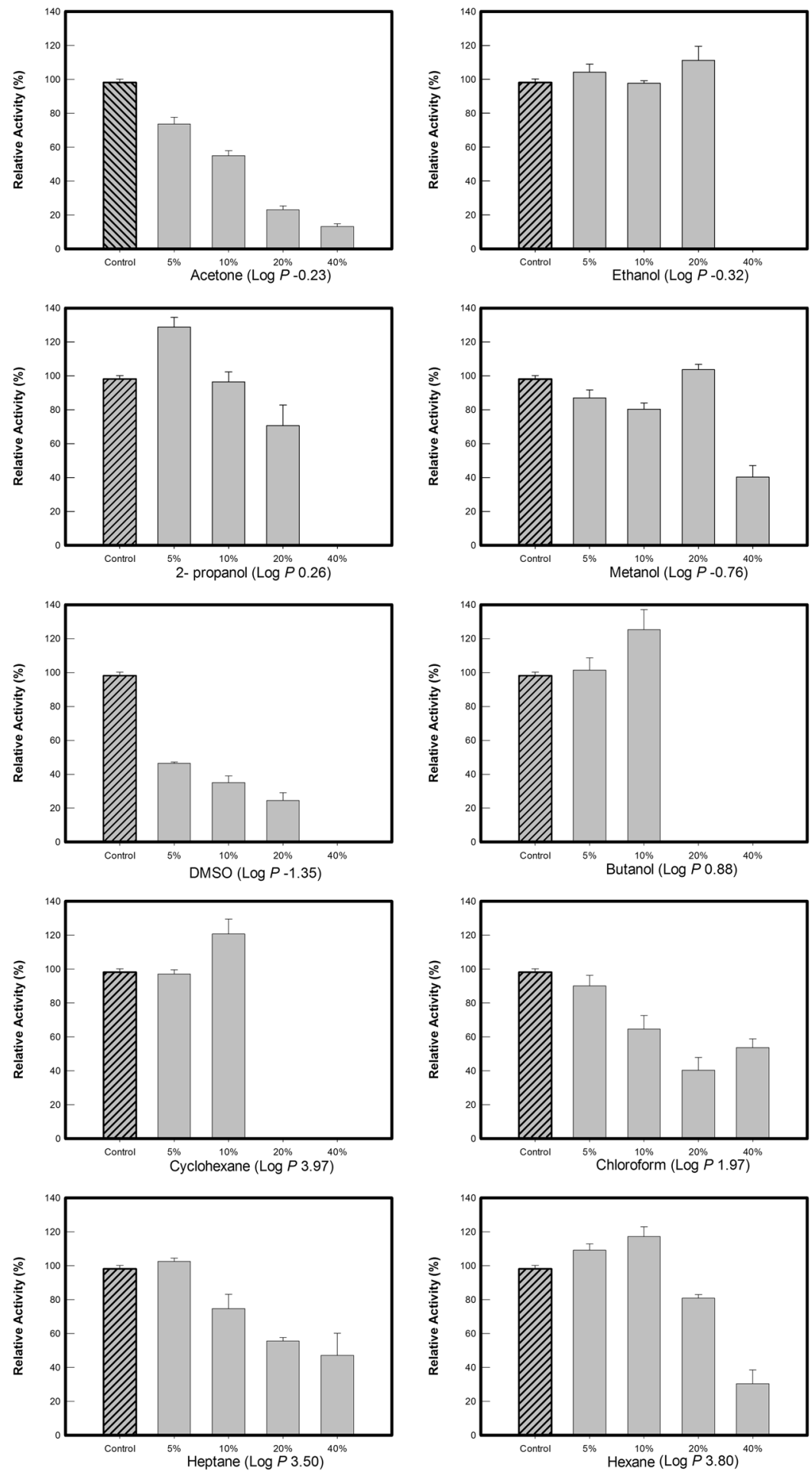

Figure 3. The effect of different organic solvents on MesoAmp activity. The remaining enzymatic activity was determined in the aqueous phase without solvent (none) under the standard conditions of the assay. The Log P (logarithm of the partition coefficient of a particular solvent between n-octanol and water) values determine the degree of hydrophobicity of the solvent. Negative values: hydrophilic solvent and positive values: hydrophobic solvent. The data are expressed as Mean \pm SD of five independent experiments.

region and an 8-element fingerprint that provides a signature for thermophilic metalloproteases (Thermoptase) and virtually spans the full alignment length ${ }^{26}$.

The structural model of MesoAmp displays a long substrate-binding hole in the N-terminal domain that functions to limit the length of the C-terminal side of the substrate. The binding pocket in the C-terminus domain provides the molecular basis for the selectivity of its residues (Fig. 2E) ${ }^{27}$. 
A

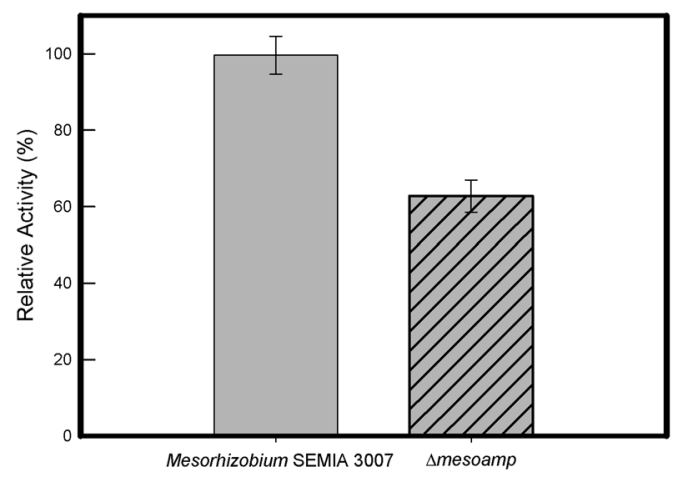

B

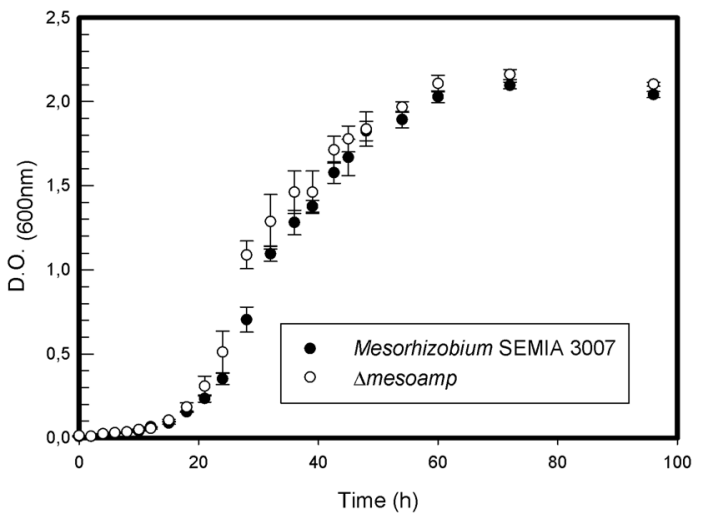

Figure 4. Aminopeptidase activity and in vitro growth kinetic assay of Mesorhizobium sp SEMIA 3007 and $\Delta$ mesoamp. (A) Enzymatic activity of Mesorhizobium sp SEMIA 3007 and $\Delta$ mesoamp strains using LeupNA as the substrate in $100 \mathrm{mM}$ bicarbonate sodium-hydroxide buffer at $\mathrm{pH} 8.5$ and $4 \mathrm{mM} \mathrm{Co}{ }^{2+}$. Values are expressed as Mean \pm SD. (B) In vitro growth curves for Mesorhizobium sp SEMIA 3007 and $\Delta$ mesoamp strains. The experiments were performed in triplicate, and the error bars indicate standard errors. The relationship of $\mathrm{OD}_{600} \mathrm{~nm}$ to viable count was equivalent for all strains examined. The data are expressed as Mean $\pm \mathrm{SD}$ of five independent experiments.

A

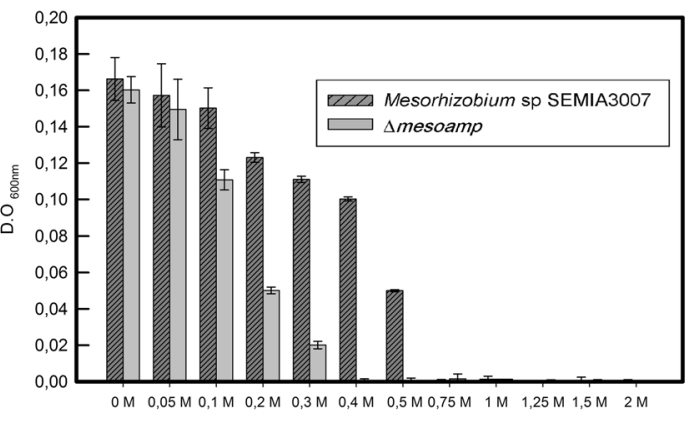

$\mathrm{NaCl}$

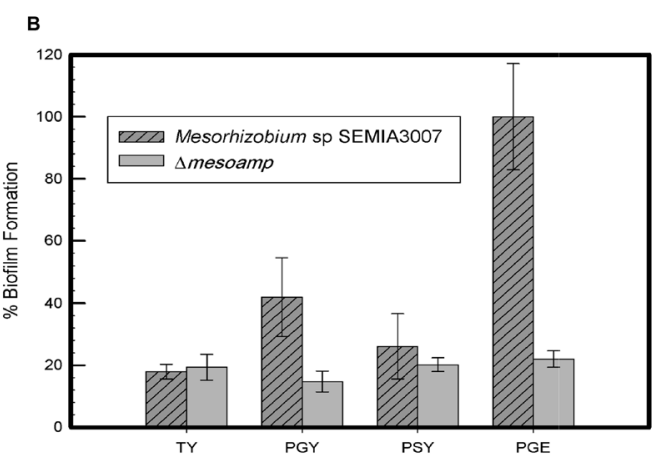

Figure 5. Biofilm production and halotolerance assay. (A) Effect of salt on growth of Mesorhizobium sp SEMIA 3007 and $\Delta$ mesoamp strains. Bacteria were inoculated in TY medium containing different salt concentrations. Each point represents the average of three replicates. (B) Biofilm formation in Mesorhizobium sp SEMIA 3007 and $\Delta$ mesoamp strains. Each value is mean $\pm S D ; n=8$. Both strains were grown in TY (as control broth), PGY (supplemented with glycerol as carbon source) and PEG (with glucose), and PSY (with sucrose). Biofilm assays were done using precoated plates. The data are expressed as Mean \pm SD of five independent experiments.

The enzymatic characterization of the MesoAmp indicated that the protein retained $80 \%$ of its enzymatic activity in an alkaline $\mathrm{pH}$ range of 7.5 to 9.0 with maximal activity at $\mathrm{pH}$ 8.5. These results are comparable with those on AmpT (optimal pH between 7.0 and 8.0) and PepS aminopeptidase (optimal pH between 7.5-8.5) ${ }^{28}$. According to Wang, T, et al. ${ }^{20}$, there is a substantial decrease in the activity outside the pH range 7.0 to 9.0 , and it is primarily due to irreversible changes in the protein structure or to the destabilization by buffer species.

The M29 family is characterized by an optimal temperature between 60 to $70^{\circ} \mathrm{C}^{17}$. In contrast, MesoAmp had its optimal activity at $40{ }^{\circ} \mathrm{C}$ and maintained $80 \%$ of its activity at $55^{\circ} \mathrm{C}$ with a decrease of $50 \%$ of its activity at $60^{\circ} \mathrm{C}$. The thermal stability of proteins seems to be a complex phenomenon that can be affected by many factors. In general, proteins can be stabilized by decreases in their entropy of unfolding ${ }^{29}$. In the primary structure of MesoAmp, the proline residue represents as much as $4.3 \%$ of the sequence. At the same time, prolines represent only $5.4 \%$ and $4.1 \%$ of the residues in the amino acid sequences of Amp T and PePS, respectively. This finding suggests that other factors are responsible for their thermal stability such as the presence of disulfide bonds formed by cysteine residues that stabilize proteins by decreasing the entropy of the protein's unfolded state ${ }^{30}$ and/ or oligomeric state formation, representing an adaptive advantage relative to their monomeric counterparts ${ }^{24}$. The ability to act at temperatures over $40^{\circ} \mathrm{C}$ is of great biotechnological importance, reducing the risk of contamination by mesophilic microorganisms. In addition, this characteristic favours substrate and product solubility and increases reaction rates for reducing viscosity and for increasing the diffusion coefficients of the substrates ${ }^{31}$.

Metalloaminopeptidases exhibit a broad range of metal ion dependence, and $\mathrm{Zn}^{2+}$ is the most frequently associated cation. Members of the M29 family from Staphylococcus aureus, B. stearothermophilus and L. 
monosytogenes have $\mathrm{Co}^{2+}$ and $\mathrm{Mg}^{2+}$ as cofactors. On the other hand, the cofactor for PepS is unknown, but it is unlikely to be $\mathrm{Ca}^{2+}, \mathrm{Cu}^{2+}, \mathrm{Zn}^{2+} \mathrm{Co}^{2+}, \mathrm{Mn}^{2+}$ and $\mathrm{Hg}^{2+}$ because low concentrations of these cations inactivated the enzyme ${ }^{32}$. MesoAmp displays a high dependence on $\mathrm{Co}^{2+}$ and $\mathrm{Mn}^{2+}$ ions, and the effect of $\mathrm{Co}^{2+}$ on aminopeptidases has been frequently described in the literature. This cation increases the relative activity from $3^{33}, 5^{34}$ to 26 times that of the normal activity ${ }^{35}$. A study focusing on density functional theory ${ }^{36}$ determined that the electronic nature of cobalt and manganese ions activates water molecules, thus influencing the generation of the intermediate state (enzyme-substrate), which consequently increases the reaction rate.

MesoAmp exhibited relative resistance in the presence of polar and non-polar solvents, and this phenomenon has been observed in many cases ${ }^{37}$. Nevertheless, the reason for such tolerance has not been established to date. To a certain extent, this solvent activation imparts conformational flexibility to the protein, causing an increase in activity. Additionally, the relative abundance of hydrophobic residues located on the surface of a molecule plays an important role in the structural stability of proteins ${ }^{37,38}$. Salt has several important effects on the stability of proteins, primarily by charge modification on the protein surface or/and alteration of charges between substrate and enzyme ${ }^{31}$. This effect can subsequently increase enzyme activity. Further studies of the tertiary structure of the aminopeptidase M29 family might clarify the molecular basis of the mechanism of its environmental adaptation at high salt concentrations.

The proteolytic machinery has a functional redundancy between several enzymes. Mesorhizobium $\mathrm{sp}$ SEMIA3007 produces enzymes with a similar metabolic function (Table S4) according to the Brenda databases ${ }^{39}$. In the absence of MesoAmp, the other enzymes with amino peptidase activity can supply the demand for intracellular amino acids required for bacterial development such as protein synthesis. For that reason, in spite of having a decrease of aminopeptidase activity in the absence of MesoAmp, the growth of Mesorhizobium in synthetic media is not affected. However, aminopeptidases may exhibit other functions in addition to the degradation of intracellular peptides and maintenance of the pool of amino acids, such as cell resistance to osmotic stress, biofilm production, and cell invasion ${ }^{40-42}$. To our knowledge, we have characterized aminopeptidase from Mesorhizobium or other rhizobacteria for the first time.

Previous work has reported the multifunctionality of aminopeptidases. In S. typhimurium, peptidases involved in exogenous peptide degradation, protein turnover and degradation of abnormal proteins ${ }^{43}$. In E. coli, PepA is also endowed with DNA binding activity in regulation of the carAB operon ${ }^{44}$. In Lactococcus lactis, PepF plays a role in the pyruvate metabolism, cell wall and protein secretion ${ }^{45}$. In S. thermophilus, PepS aminopeptidase has cellular functions as peptidoglycan metabolism ${ }^{12}$. Our results suggest that MesoAmp is indispensable for biofilm production and osmotic stress tolerance (Table 4), functions totally undescribed for other aminopeptidases. However, considering that there is no growth defect in the $\Delta$ mesoamp strain that might account for decreased biofilm production, we suggest that MesoAmp plays a non-nutritional role. The mechanism by which aminopeptidases affect the synthesis of biofilms is not well understood, because their formation and maintenance are multifactorial processes influenced mainly by production and nature of the intra- and extracellular polysaccharides ${ }^{46}$. For Mesorhizobium, the fact that MesoAmp contributes to biofilm production might be attributed to the ability of this enzyme to catalyse the peptides to release free leucine and other amino acids that serve as a substrate for a variety of catabolic pathways ${ }^{47}$. In the absence of MesoAmp, the mutant cannot keep that pool of amino acids, thus making it sensitive to osmotic stress. Many species of bacteria have also been shown to increase the proline and leucine pool size and accumulate total free amino acids under osmotic stress contributing to their adaptability to a saline environment ${ }^{47-49}$.

\section{Conclusions}

The major problem of bioprocesses today is the uncompetitive production costs compared to chemical synthesis. High fresh water, energy consuming sterilization, discontinuous fermentation to avoid microbial contamination and the solubility of non-polar substrates ${ }^{50}$ increase production costs. Enzymes with new physicochemical properties (thermo-, solvent- and halo-tolerance) can reduce economic costs, making these enzymes more profitable for industrial bioprocesses. Our bioinformatics approach can greatly shorten the working time ${ }^{51}$ resulting in a significant advantage over conventional methods. Furthermore, in certain cases, along with the metagenomic approach $^{29}$, it is possible to identify new enzymes with high biotechnological potential in a sea of bioinformatics data. Some thermo-tolerant ${ }^{52}$, solvent-tolerant ${ }^{20}$ and halo-tolerant ${ }^{53}$ aminopeptidases have been reported, however, none display all three features simultaneously (see Table 4).

It is very difficult to elucidate the pleiotropic functions of mesoamp, mainly due to the complexity of biological systems. We have increased our knowledge of aminopeptidases in the M29 family and confirmed their involvement in the biofilm synthesis and resistance to osmotic stress, but the precise mechanisms by which it interferes with these cellular functions is still unclear. This situation encourages the development of complex and precise biological models that take into account pleiotropy and the connection of all other cellular functions.

\section{Materials and Methods}

The de novo sequencing of Mesorhizobium SEMIA3007 genome used a combined strategy involving Illumina - HiscanSQ. The prediction of ORFs and annotation were performed using the Rast system ${ }^{54}$ and deposited in the Laboratory of Biochemistry of Microorganisms and Plants (LBMP) database at São Paulo State University, Jaboticabal Campus. The data sets results are available in the NCBI BioProject SRR3703040 55

Homology search and comparative sequence analysis. The annotation of the assembled sequence was conducted using RAST (Rapid Annotation Using Subsystem Technology) ${ }^{56}$. A search for ORFs that encode peptidases was performed, and the selected ORFs were compared individually in the MEROPS peptidase database using the local alignment tool (http://merops.sanger.ac.uk/index.shtml). 


\begin{tabular}{|c|c|c|c|}
\hline Name & M.O. & Characteristic & Reference \\
\hline leucine aminopeptidase II & Bacillus stearothermophilus & $\begin{array}{l}\text { - Homodimer- } \mathrm{pH} \text { and temperature optimum for the } \\
\text { hydrolysis reaction was } \mathrm{pH} 8.0 \text { and } 60^{\circ} \mathrm{C} .-\mathrm{Co}^{2+} \text { ions have a } \\
\text { stimulatory effect }\end{array}$ & 76 \\
\hline Aminopeptidase & Borrelia burgdorferi & $\begin{array}{l}\text { - Homohexameric- } \mathrm{pH} \text { and temperature optimum for the } \\
\text { hydrolysis reaction was } \mathrm{pH} 7.5 \text { and } 60^{\circ} \mathrm{C} .-\mathrm{Zn}^{2+} \text { ions have a } \\
\text { stimulatory effect }\end{array}$ & 24 \\
\hline Aminopeptidase $\mathrm{T}$ & Listeria monocytogenes & $\begin{array}{l}\text { - Homodimer- Strongly stimulated by } \mathrm{Co}^{2+} \text { - Virulence Factor } \\
\text { for infection }\end{array}$ & 13 \\
\hline Aminopeptidase PepS & Streptococcus thermophiles & $\begin{array}{l}\text { - Aminopeptidase PepS probably plays a pleiotropic role } \\
\text { through its involvement in growth via nitrogen nutrition }\end{array}$ & 12 \\
\hline Alkaline Aminopeptidase & Bacillus mycoides & $\begin{array}{l}\text { - Monomer- } \mathrm{pH} \text { optimum for the hydrolysis reaction was 9.0.- } \\
\mathrm{Co}^{2+} \text { ions have a stimulatory effect- After } 30 \text { min preincubation } \\
\text { at } 45^{\circ} \mathrm{C} \text { the aminopeptidase retained only } 12 \% \text { of activity. }\end{array}$ & 77 \\
\hline leucine aminopeptidase LAP & Staphylococcus aureus & $\begin{array}{l}\text { - High activity in the presence of } \mathrm{Mn}^{2+}-\mathrm{pH} \text { optimum for the } \\
\text { hydrolysis reaction was } 8.5 \text { - broad substrate range that extends } \\
\text { beyond leucine }\end{array}$ & 41 \\
\hline Thermostable aminopeptidase & Aquifex aeolicus & $\begin{array}{l}\text { - } \mathrm{pH} \text { and temperature optimum for the hydrolysis reaction was } \\
\mathrm{pH} 8.0 \text { to } 8.5 \text { and } 80^{\circ} \mathrm{C} \text {.- Highly resistant to organic solvents. }\end{array}$ & 78 \\
\hline PseA PepB & Pseudomonas aeruginosa & $\begin{array}{l}\text { - } \mathrm{pH} \text { and temperature optimum for } 6.0 \text { to } 8.0 \text { and appreciably } \\
\text { thermostable up to } 70^{\circ} \mathrm{C} \text {.- Remarkable stability in both } \\
\text { hydrophilic and hydrophobic solvents. }\end{array}$ & 38 \\
\hline BsAmpII & Bacillus stearothermophilus & $\begin{array}{l}\text { - Homodimer- Active and stable at pHs ranging from } 6.5 \text { to } \\
\text { 8.5- Secondary structures of BsAmpII are not altered in the } \\
\text { presence of } 5-10 \% \text { acetone and ethanol- Remained active at } \\
\text { concentrations of urea below } 2.7 \mathrm{M}\end{array}$ & 20 \\
\hline Leucine Aminopeptidase & Bacillus sp. N2 & $\begin{array}{l}\text { - Monomeric- } \mathrm{pH} \text { and temperature optimum for the hydrolysis } \\
\text { reaction was } \mathrm{pH} 9.5 \text { and } 50^{\circ} \mathrm{C} \text {.- } \mathrm{Co}^{2+} \text { ions have a stimulatory } \\
\text { effect.- hydrolytic activity in high concentrations of } \mathrm{NaCl} \text { (up } \\
\text { to } 4 \mathrm{M} \text { ) }\end{array}$ & 79,80 \\
\hline Mesoamp & Mesorhizobium SEMIA 3007 & $\begin{array}{l}\text { - Homodimer- Strongly stimulated by } \mathrm{Co}^{2+} \text { and } \mathrm{Mn}^{2+} .-\mathrm{pH} \\
\text { and temperature optimum for the hydrolysis reaction was } \mathrm{pH} \\
8.5 \text { and } 45^{\circ} \mathrm{C} \text {, and maintained } 80 \% \text { of its activity at } 55^{\circ} \mathrm{C} \text {.- } \\
\text { Remarkable stability in organic solvents and was active at } \\
\text { high concentrations of NaCl.- Responsible for } 40 \% \text { of the } \\
\text { organism's aminopeptidase activity.- Pleiotropic role through } \\
\text { its involvement biofilms formation and halotolerance. }\end{array}$ & This work \\
\hline
\end{tabular}

Table 4. Biochemical and physiological properties of the M29 family aminopeptidases.

mesoamp sequence analysis. Protein signatures and conserved motifs were examined using InterProScan ${ }^{26}$, and the theoretical physiochemical data were generated with the ProtParam tool from ExPASy (http://www.expasy.org/). To estimate the evolutionary conservation of each amino acid translated from the mesoamp gene, its sequence was aligned with 24 amino acid sequence from the aminopeptidase members of the M29 family (Table S1) using the CLUSTAL W programme ${ }^{57}$. The alignment was analysed with the ConSurf server ${ }^{58}$. Additionally, an analysis was performed with the SignalP 4.1 server $^{59}$ in order to identify possible signal peptides.

Molecular modelling. A search for proteins structurally similar to MesoAmp was performed using BLASTP against the Protein Data Bank (PDB). The molecular models of the enzyme were built using the Modeller 9.10 programme ${ }^{60}$ with the default parameters based on the structural coordinates of the aminopeptidase PepS from Streptococcus pneumoniae (PDB code: 4ICQ) ${ }^{27}$, the aminopeptidase T from Thermus thermophilus (PDB code: $2 \mathrm{AYI})^{61}$ and the aminopeptidase S from Staphyloccus aureus (PDB code: 1ZJC) ${ }^{62}$. A quality assessment of the models was performed by ModFold ${ }^{63}$. The scores of the amino acid position conservation displayed by the Consurf server were projected onto the MesoAmp structure. The molecular docking was calculated using M-ZDOCK ${ }^{64}$. The cavity volumes were calculated by KVfinder ${ }^{65}$, and the PyMOL software ${ }^{66}$ was used to visualize the models and to prepare the figures.

DNA cloning, heterologous overexpression and protein purification. Preparation of plasmids, DNA manipulations, and transformation of E. coli BL21(DE3) competent cells were performed as previously described ${ }^{67,68}$ using the following synthetic oligonucleotides: Forward $5^{\prime}$ CAGGCATATGATCATGA CCACACATTCG $3^{\prime}$ and Reverse $5^{\prime}$ CGAACTCGAGCCCTCAGGCCCACT $3^{\prime}$ that had sites for the restriction enzymes NdeI and XhoI, respectively (underlined). The protein concentration was determined using spectrophotometer analysis with a Nanodrop ND-1000 with the theoretical extinction coefficient $\left(54680 \mathrm{M}^{-1} \mathrm{~cm}^{-1}\right)$ obtained from the ProtParam tool and the Bradford method ${ }^{69}$ with bovine serum albumin (BSA) as a reference.

Size exclusion chromatography for molecular mass determination. The protein samples were analysed using 10\% sodium dodecyl sulfate polyacrylamide gel electrophoresis (SDS-PAGE). The gel was stained with Coomassie Brilliant Blue G-250 and destained with $10 \%(\mathrm{v} / \mathrm{v})$ acetic acid $^{70}$. The molecular mass of the native enzyme was estimated by size exclusion chromatography (SEC) using a Hiload16/600 Superdex 200 column (GE Healthcare Bio-Sciences, Uppsala, Sweden) previously equilibrated with purification buffer (100 mM Tris- $\mathrm{HCl}$ $\mathrm{pH} 8.0 ; 200 \mathrm{mM} \mathrm{NaCl} ; 5 \%$ (w/v) glycerol). The calibration curve was obtained using the Protein Standard Mix 
15-600 kDa (Sigma-Aldrich, St. Louis, MO.), which contains standard proteins [thyroglobulin bovine (670 kDa); $\gamma$-globulins (150 kDa); Albumin (44.3 kDa); Ribonuclease A (13.7 kDa); and P-aminobenzoic acid (pABA) $(0.13$ $\mathrm{kDa})$ ], and then plotting the log of the molecular weight of the protein against the elution volume (ml). From this calibration curve, the molecular weight of MesoAmp was determined. The chromatograms were obtained by measuring the absorbance at $280 \mathrm{~nm}$ using an ÄKTA pure system (GE Healthcare) at a flow rate of $0.5 \mathrm{~mL} \mathrm{~min}^{-1}$. All collected fractions were analysed by SDS-PAGE, and the fraction containing pure MesoAmp was used for further assays.

Kinetic assays. Aminopeptidase activity was measured by spectrophotometric detection via the hydrolysis of L-leucine-p-nitroanilide (Leu-p-NA) ${ }^{20}$ by continuously monitoring the p-nitrophenol (p-NA) release at $405 \mathrm{~nm}$ using the spectrophotometer reader MultiScan Go (Thermo Scientific). The molar extinction coefficient $(\varepsilon \mathrm{pNA}=9,620)$ was used to calculate the enzymatic activity. Unless otherwise indicated, the reaction was performed using $1 \mu \mathrm{g}$ of pure MesoAmp in $20 \mathrm{mM}$ Tris- $\mathrm{HCl} \mathrm{pH} 8.0$ buffer at room temperature in a final volume of $200 \mu \mathrm{L}$. The assays were carried out in triplicate, and a control was performed for each reaction without the enzyme to measure the spontaneous hydrolysis of the substrates. Linear regressions were performed to determine the initial velocity (Vo) of the reaction.

Effect of $\mathrm{pH}$ and temperature on enzymatic activity. The effect of $\mathrm{pH}$ on MesoAmp activity was determined at $35^{\circ} \mathrm{C}$ using the following buffers at $100 \mathrm{mM}$ : McIlvaine ( $\mathrm{pH} 3.0$ to 4.5); sodium citrate ( $\mathrm{pH} 4.0$ to 6.5); sodium phosphate (6.5 to 8.0); Tris- $\mathrm{HCl}$ ( $\mathrm{pH} 7.0$ to 8.5); bicarbonate-sodium hydroxide (8.5 to 11.0); glycine-sodium hydroxide ( 8.5 to 10.5 ) and monosodium phosphate - sodium hydroxide (11.0 to 12.0). The optimal temperature was determined in the range of 10 to $90^{\circ} \mathrm{C}$ using $5^{\circ} \mathrm{C}$ or $10^{\circ} \mathrm{C}$ steps. After these preliminary experiments, the assays were carried out in $100 \mathrm{mM}$ Tris- $\mathrm{HCl}$ buffer $\mathrm{pH} 8.5$ at $40^{\circ} \mathrm{C}$.

To verify the thermostability of MesoAmp, an activity assay was performed under the temperature range of $40^{\circ} \mathrm{C}$ to $70^{\circ} \mathrm{C}$ by pre-incubating the purified enzyme for $5,15,30,45$ or 60 minutes followed by an immediate ice bath at $4^{\circ} \mathrm{C}$ for 10 minutes. The residual activity was determined after each incubation time.

Effect of metal ions, peptidase inhibitor agents and detergents on the enzymatic activity. To evaluate the influence of metal ions on MesoAmp activity, $2 \mathrm{mM}$ (final concentration) of $\mathrm{K}^{+}, \mathrm{Mg}^{2+}, \mathrm{Ca}^{2+}, \mathrm{Mn}^{2+}$, $\mathrm{Co}^{2+}, \mathrm{Cu}^{+2}, \mathrm{Fe}^{+2}, \mathrm{Ni}^{+2}, \mathrm{Al}^{+3}, \mathrm{Li}^{+}, \mathrm{Zn}^{2+}, \mathrm{Hg}^{2+}, \mathrm{Cd}^{2+} \mathrm{Or} \mathrm{Ba}^{2+}$ was added to the enzyme solution, and the residual activity was measured. A control without metal ions was used to calculate the residual activity.

Specific peptidase inhibitors were added to the enzyme solution $(10 \mathrm{mM})$ including phenylmethylsulfonyl fluoride (PMSF) or iodoacetic acid that inhibit serine protease and cysteine protease, respectively, and ethylenediamine tetraacetic acid (EDTA) $(5,10$ and $20 \mathrm{mM})$, that inhibits metalloproteases.

The effects of detergents on MesoAmp activity was investigated using Tween 20, Tween 80, Triton X-100 and Triton X114 at $0.5 \%, 1 \%$ and $2 \%(\mathrm{w} / \mathrm{v})$. The enzyme was incubated with each detergent at room temperature for $30 \mathrm{~min}$. The residual activity was determined and compared to the control. The procedure for the analysis of the effects of ionic surfactants was the same as above except that the enzyme was treated with sodium dodecyl sulfate (SDS) or hexadecyl trimethyl ammonium bromide (CTAB) at $1 \%, 2 \%$ and $4 \%(\mathrm{w} / \mathrm{v})$.

Effect of denaturing agents and organic solvents on the enzymatic activity. The effects of urea, guanidine (0.5, 1 and $2 \mathrm{M}), \mathrm{NaCl}(0.5,1,2,3$ and $4 \mathrm{M})$, Dithiothreitol (DTT) and $\beta$-mercaptoethanol (1, 5 and 10 $\mathrm{mM}$ ) on the activity of MesoAmp were investigated. Samples were incubated at room temperature for $45 \mathrm{~min}$, and the residual activity was determined and compared to the control.

The stability of MesoAmp in the presence of organic solvents was assessed by measuring the residual activity of the enzyme after incubating it at $4^{\circ} \mathrm{C}$ for $45 \mathrm{~min}$ with $5,10,20$, and $40 \%(\mathrm{v} / \mathrm{v})$ of methanol, ethanol, 2- propanol, acetone, chloroform, butanol, cyclohexane, hexane, heptane or dimethyl sulfoxide (DMSO). The resulting activity was compared to the control.

Kinetic parameters of purified MesoAmp. The $\mathrm{K}_{\mathrm{m}}, \mathrm{V}_{\max }$ and $\mathrm{K}_{\text {cat }}$ parameters were calculated from the initial rates of the hydrolysis of Leu-p-NA in the concentration range of 0.05 to $2.5 \mathrm{mM}$ at the optimal conditions for the enzyme, and the non-linear regression of the data using the Michaelis-Menten equation was performed by GraphPad Prism, Version 5.00 for Windows (GraphPad Software, San Diego California USA, www.graphpad.com).

All data obtained were analysed using the $\mathrm{R}$ software. An ANOVA and Tukey's test at $5 \%$ probability were used to compare the treatment methods.

Circular dichroism and thermostability measurements. The circular dichroism (CD) analysis of the purified MesoAmp was performed using a JASCO J-815 spectropolarimeter (Jasco, Tokyo, Japan) linked to a PFD-425S Peltier temperature controller. The enzyme was analysed at $4.4 \mu \mathrm{mol}$ in $5 \mathrm{mM}$ sodium phosphate, $\mathrm{pH}$ 8.0 , in the presence and absence of $8.8 \mu \mathrm{mol} \mathrm{Co} \mathrm{Co}^{2+}$. The average of thirty consecutive scans was recorded over a wavelength range of 200 to $260 \mathrm{~nm}$ using a $1 \mathrm{~mm}$ cuvette, and for both assays, the buffer baseline was subtracted. The thermostability of the enzyme was verified, and its thermal unfolding was monitored by the changes in ellipticity at $222 \mathrm{~nm}$. The temperature was increased with a heating rate of $1^{\circ} \mathrm{C} \mathrm{min}-1$ in the range of 20 to $105^{\circ} \mathrm{C}$. The melting point $(\mathrm{Tm})$ represents the temperature at the midpoint of the unfolding transition ${ }^{71}$.

Construction of mesoamp deletion mutant. To generate the $\Delta$ mesoamp allelic replacement plasmid, 510 and $543 \mathrm{bp}$ DNA fragments located upstream and downstream of the mesoamp open reading frame were amplified 
by PCR and cloned into the nonreplicating vector pNPTS138 ${ }^{72}$. The upstream DNA fragment was amplified using primers $\mathrm{P}(\mathrm{A}) \mathrm{F}-5^{\prime}$ TGCGGATCCTGGCGCAGGAAGTGTT $3^{\prime}$ (BamHI restriction sites are underlined), and $\mathrm{P}(\mathrm{B}) \mathrm{R}$ - 5' CCTCCCTACGTGGGAATCTGACCCATA $3^{\prime}$. The downstream DNA fragment was PCR amplified using primers $\mathrm{P}(\mathrm{C}) \mathrm{F}-5^{\prime}$ GATTCCCACGTAGGGAGGTCGAATGGC $3^{\prime}$ and $\mathrm{P}(\mathrm{D}) \mathrm{R}-5^{\prime} \mathrm{CTG}$ GAATTCGTC GGGGACCGGGTTCTG 3' (EcoRI restriction sites are underlined). A stable in-frame deletion of mesoamp was generated by homologous recombination and allelic replacement using an SOE-PCR. The DNA fragment, framed by BamHI and EcoRI sites, was cloned into a BamHI and EcoRI-digested pNPTS138 to generate plasmid pJL38 $\Delta$ mesoamp. Mesorhizobium SEMIA3007 electro-competent cells, and electroporation was carried out using the conventional method ${ }^{73}$. Transformant cells with pJL38 $\Delta$ mesoamp integrated upstream of the mesoamp locus were obtained by selecting for kanamycin resistance. The recombinants were identified as kanamycin-sensitive colonies and confirmed by PCR with primers $\mathrm{P}(\mathrm{A}) \mathrm{F}$ and $\mathrm{P}(\mathrm{D}) \mathrm{R}$. The resultant in-frame deletion mutant was further verified by DNA sequencing and finally designated $\Delta$ mesoamp strain.

Growth, biofilm production and halotolerance assay. To determine the potential role of aminopeptidases in Mesorhizobium sp physiology, $\Delta$ mesoamp mutant was evaluated in conditions of osmotic and thermic stress and in biofilm production. For routine growth, TY broth ${ }^{74}$ was used. The initial $\mathrm{OD}_{600 \mathrm{~nm}}$ of each bacterial suspension was adjusted to 0.05 as a starting time point $(0 \mathrm{~h})$. The bacterial cultures were incubated at $30^{\circ} \mathrm{C}$ with shaking at $200 \mathrm{rpm}$ and kinetic growth was measured (oD600 nm) at $2 \mathrm{~h}$ interval for 96 hours.

For comparative analyses of the biofilm production by the wild-type and mutant strains TY, $\mathrm{PSY}\left(\mathrm{K}_{2} \mathrm{HPO}_{4} 1.4\right.$ $\mathrm{g}^{-1}, \mathrm{KH}_{2} \mathrm{PO}_{4} 1.0 \mathrm{~g}^{-1}, \mathrm{MgSO}_{4} 0.2 \mathrm{~g}^{-1}$, sucrose $10 \mathrm{~g}^{-1}$, yeast extract $\left.1.0 \mathrm{~g}^{-1}\right)$, PGY $\left(\mathrm{K}_{2} \mathrm{HPO}_{4} 1.4 \mathrm{~g}^{-1}, \mathrm{KH}_{2} \mathrm{PO}_{4} 1.0 \mathrm{~g}^{-1}\right.$, $\mathrm{MgSO}_{4} 0.2 \mathrm{~g}^{-1}$, glycerol $10 \mathrm{~g}^{-1}$, yeast extract $\left.1.0 \mathrm{~g}^{-1}\right)$ and PGE $\left(\mathrm{K}_{2} \mathrm{HPO}_{4} 0.5 \mathrm{~g}^{-1}, \mathrm{MgSO}_{4} 0.2 \mathrm{~g}^{-1}, \mathrm{NaCl} 0.1 \mathrm{~g}^{-1}\right.$, yeast extract $3.0 \mathrm{~g}^{-1}$ and glucose $10.0 \mathrm{~g}^{-1}$ ) broth were used, following incubation at $30^{\circ} \mathrm{C}$ with shaking at $200 \mathrm{rpm}$ for $144 \mathrm{~h}$. Then, the biofilms were stained by crystal violet methods as previously described ${ }^{75}$. To investigate halotolerance, Mesorhizobium SEMIA3007 and $\Delta$ mesoamp strain were inoculated into TY broth for $24 \mathrm{~h}$ at $30^{\circ} \mathrm{C}$ with constant shaking at $200 \mathrm{rpm}$ until the exponential growth phase was reached. Then, the density was estimated spectrophotometrically to achieve an approximate starting concentration $\left(\mathrm{OD}_{600 \mathrm{~nm}}=0.5\right)$. The bacterial cultures were incubated into TY broth containing $0.05,0.1,0.2,0.3,0.4,0.5,0.75,1.0 ; 1.25,1.50$ or $2 \mathrm{M}$ of $\mathrm{NaCl}$, at $30^{\circ} \mathrm{C}$ with shaking at $200 \mathrm{rpm}$ and the $\mathrm{OD}_{600 \mathrm{~nm}}$ was monitored for $72 \mathrm{~h}$ every twenty-four hours.

Nucleotide sequence accession number. The DNA sequence of mesoamp gene was deposited at GenBank with the reference code WP_069093355.1.

\section{References}

1. Ghobakhlou, A.-F., Johnston, A., Harris, L., Antoun, H. \& Laberge, S. Microarray transcriptional profiling of Arctic Mesorhizobium strain N33 at low temperature provides insights into cold adaption strategies. BMC Genomics 16, 383 (2015).

2. Krick, A. et al. A Marine Mesorhizobium sp. Produces Structurally Novel Long-Chain N-Acyl-L-Homoserine Lactones. Appl. Environ. Microbiol. 73, 3587-3594 (2007).

3. Diouf, F. et al. Genetic and Genomic Diversity Studies of Acacia Symbionts in Senegal Reveal New Species of Mesorhizobium with a Putative Geographical Pattern. PLoS One 10, e0117667 (2015).

4. Teng, Y. et al. Isolation of the PCB-degrading bacteria Mesorhizobium sp. ZY1 and its combined remediation with Astragalus sinicus L. for contaminated soil. Int. J. Phytoremediation 20 (2015).

5. Venkatachalam, G., Nandakumar, V., Suresh, G. \& Doble, M. Characterization and applications of cyclic $\beta$ - $(1,2)$-glucan produced from R. meliloti. RSC Adv. 4, 11393 (2014).

6. Uechi, K., Takata, G., Fukai, Y., Yoshihara, A. \& Morimoto, K. Gene Cloning and Characterization of L-Ribulose 3-epimerase from Mesorhizobium loti and its Application to Rare Sugar Production. Biosci. Biotechnol. Biochem. 77, 511-515 (2013).

7. Kim, J. et al. Cloning and characterization of a novel $\beta$-transaminase from Mesorhizobium sp. strain LUK: A new biocatalyst for the synthesis of enantiomerically pure??-amino acids. Appl. Environ. Microbiol. 73, 1772-1782 (2007).

8. Prasad, M. P. \& Sethi, R. Optimization of cellulase production from a novel bacterial isolate Mesorhizobium sp. from marine source. J. Enzym. Res. 4, 39-45 (2013).

9. Takata, G. et al. Characterization of Mesorhizobium loti L -Rhamnose Isomerase and Its Application to L -Talose Production. Biosci. Biotechnol. Biochem. 75, 1006-1009 (2011).

10. Mugo, A. N. et al. Crystal structure of pyridoxine 4-oxidase from Mesorhizobium loti. Biochim. Biophys. Acta 1834, 953-63 (2013).

11. Huang, W. et al. The Structure and Enzyme Characteristics of a Recombinant Leucine Aminopeptidase rLapl from Aspergillus sojae and Its Application in Debittering. Appl. Biochem. Biotechnol. 177, 190-206 (2015).

12. Thomas, S., Besset, C., Courtin, P. \& Rul, F. The role of aminopeptidase PepS in the growth of Streptococcus thermophilus is not restricted to nitrogen nutrition. J. Appl. Microbiol. 108, 148-157 (2010).

13. Cheng, C. et al. Aminopeptidase T of M29 Family Acts as A Novel Intracellular Virulence Factor for Listeria monocytogenes Infection. Sci. Rep. 5, 17370 (2015).

14. Hernández-Moreno, A. V. et al. Kinetics and conformational stability studies of recombinant leucine aminopeptidase. Int. J. Biol. Macromol. 64, 306-312 (2014).

15. Ramírez-Zavala, B., Mercado-Flores, Y., Hernández-Rodríguez, C. \& Villa-Tanaca, L. Purification and characterization of a lysine aminopeptidase from Kluyveromyces marxianus. FEMS Microbiol. Lett. 235, 369-375 (2004).

16. Ding, G., Zhou, N. \& Tian, Y. Over-Expression of a Proline Specific Aminopeptidase from Aspergillus oryzae JN-412 and Its Application in Collagen Degradation. Appl. Biochem. Biotechnol. 173, 1765-1777 (2014).

17. Rawlings, N. D., Waller, M., Barrett, A. J. \& Bateman, A. MEROPS: The database of proteolytic enzymes, their substrates and inhibitors. Nucleic Acids Res. 42, 343-350 (2014).

18. Rawlings, N. D. \& Barrett, A. J. Evolutionary families of metallopeptidases. Methods Enzymol. 248, 183-228 (1995).

19. Bailey, S., Ward, D., Middleton, R., Grossmann, J. G. \& Zambryski, P. C. Agrobacterium tumefaciens VirB8 structure reveals potential protein-protein interaction sites. Proc. Natl. Acad. Sci. 103, 2582-2587 (2006).

20. Wang, T.-F., Lin, M.-G., Lo, H.-F., Chi, M.-C. \& Lin, L.-L. Biophysical characterization of a recombinant aminopeptidase II from the thermophilic bacterium Bacillus stearothermophilus. J. Biol. Phys. 40, 25-40 (2014).

21. Zhuo, S. \& Dixon, J. E. Effects of sulfhydryl regents on the activity of lambda Ser/Thr phosphoprotein phosphatase and inhibition of the enzyme by zinc ion. Protein Eng. 10, 1445-52 (1997).

22. Mukhopadhyay, A. Tolerance engineering in bacteria for the production of advanced biofuels and chemicals. Trends Microbiol. 23, 498-508 (2015) 
23. Sardessai, Y. \& Bhosle, S. Tolerance of bacteria to organic solvents. Res. Microbiol. 153, 263-268 (2002).

24. Bertin, P. B. et al. The thermophilic, homohexameric aminopeptidase of Borrelia burgdorferi is a member of the M29 family of metallopeptidases. Infect. Immun. 73, 2253-2261 (2005).

25. Fernandez-Espla, M. D. \& Rul, F. PepS from Streptococcus thermophilus: A new member of the aminopeptidase T family of thermophilic bacteria. Eur. J. Biochem. 263, 502-510 (1999).

26. Mitchell, A. et al. The InterPro protein families database: the classification resource after 15 years. Nucleic Acids Res. 43, D213-D221 (2015).

27. Ta, H. M. et al. Structure-based elucidation of the regulatory mechanism for aminopeptidase activity. Acta Crystallogr. Sect. D Biol. Crystallogr. 69, 1738-1747 (2013).

28. Rul, F. In Handbook of Proteolytic Enzymes (eds Rawlings, N. D. \& Salvesen, G.) 1677-1678 (Academic Press publications - Elsevier). doi:10.1016/B978-0-12-382219-2.00380-X (2013).

29. Plotka, M. et al. Novel Highly Thermostable Endolysin from Thermus scotoductus MAT2119 Bacteriophage Ph2119 with Amino Acid Sequence Similarity to Eukaryotic Peptidoglycan Recognition Proteins. Appl. Environ. Microbiol. 80, 886-895 (2014).

30. Vieille, C., Zeikus, G. J. \& Vieille, C. Thermostability Hyperthermophilic Enzymes: Sources, Uses, and Molecular Mechanisms for Thermostability. Microbiol. Mol. Biol. Rev. 65, 1-43 (2001).

31. Merheb-Dini, C. et al. Biochemical and functional characterization of a metalloprotease from the thermophilic fungus thermoascus aurantiacus. J. Agric. Food Chem. 57, 9210-9217 (2009).

32. Handbook of Proteolytic Enzymes. Protein Science 8, (Academic Press, 2013).

33. Kuo, L.-Y., Hwang, G.-Y., Lai, Y.-J., Yang, S.-L. \& Lin, L.-L. Overexpression, purification, and characterization of the recombinant leucine aminopeptidase II of Bacillus stearothermophilus. Curr. Microbiol. 47, 40-45 (2003).

34. Dong, L. et al. The leucyl aminopeptidase from Helicobacter pylori is an allosteric enzyme. Microbiology 151, 2017-2023 (2005).

35. Wang, F. et al. Biochemical Properties of Recombinant Leucine Aminopeptidase II from Bacillus stearothermophilus and Potential Applications in the Hydrolysis of Chinese Anchovy (Engraulis japonicus) Proteins. J. Agric. Food Chem. 60, 165-172 (2012).

36. Zhu, X. et al. Mechanism of peptide hydrolysis by co-catalytic metal centers containing leucine aminopeptidase enzyme: A DFT approach. J. Biol. Inorg. Chem. 17, 209-222 (2012).

37. Doukyu, N. \& Ogino, H. Organic solvent-tolerant enzymes. Biochem. Eng. J. 48, 270-282 (2010).

38. Gaur, R., Grover, T., Sharma, R., Kapoor, S. \& Khare, S. K. Purification and characterization of a solvent stable aminopeptidase from Pseudomonas aeruginosa: Cloning and analysis of aminopeptidase gene conferring solvent stability. Process Biochem. 45, 757-764 (2010).

39. Chang, A. et al. BRENDA in 2015: exciting developments in its 25th year of existence. Nucleic Acids Res. 43, D439-46 (2015).

40. Carroll, R. K. et al. Identification of an intracellular M17 family leucine aminopeptidase that is required for virulence in Staphylococcus aureus. Microbes Infect. 14, 989-999 (2012).

41. Carroll, R. K. et al. The Staphylococcus aureus leucine aminopeptidase is localized to the bacterial cytosol and demonstrates a broad substrate range that extends beyond leucine. Biol. Chem. 394, 1199-1216 (2013).

42. Singh, A. K., Singh, R., Tomar, D., Pandya, C. D. \& Singh, R. The leucine aminopeptidase of Staphylococcus aureus is secreted and contributes to biofilm formation. Int. J. Infect. Dis. 16, e375-e381 (2012).

43. Miller, C. G. \& Green, L. Degradation of abnormal proteins in peptidase-deficient mutants of Salmonella typhimurium. J. Bacteriol. 147, 925-30 (1981)

44. Charlier, D. et al. Mutational analysis of Escherichia coli PepA, a multifunctional DNA-binding aminopeptidase 11 Edited by M. Yaniv. J. Mol. Biol. 302, 409-424 (2000).

45. Kleine, L. L., Monnet, V., Pechoux, C. \& Trubuil, A. Role of bacterial peptidase F inferred by statistical analysis and further experimental validation. HFSP J. 2, 29-41 (2008).

46. Beenken, K. E., Blevins, J. S. \& Smeltzer, M. S. Mutation of sarA in Staphylococcus aureus Limits Biofilm Formation. Infect. Immun. 71, 4206-4211 (2003).

47. Díaz-Pérez, A. L., Díaz-Pérez, C. \& Campos-García, J. Bacterial l-leucine catabolism as a source of secondary metabolites. Rev. Environ. Sci. Biotechnol. 15, 1-29 (2015).

48. Measures, J. Role of amino acids in osmoregulation of non-halophilic bacteria. Nature 257, 398-400 (1975).

49. Bharti, N., Yadav, D., Barnawal, D., Maji, D. \& Kalra, A. Exiguobacterium oxidotolerans, a halotolerant plant growth promoting rhizobacteria, improves yield and content of secondary metabolites in Bacopa monnieri (L.) Pennell under primary and secondary salt stress. World J. Microbiol. Biotechnol. 29, 379-387 (2013).

50. Li, W., Zhou, R. \& Mu, Y. Salting effects on protein components in aqueous $\mathrm{NaCl}$ and urea solutions: Toward understanding of ureainduced protein denaturation. J. Phys. Chem. B 116, 1446-1451 (2012).

51. Gong, J.-S. et al. Metagenomic technology and genome mining: emerging areas for exploring novel nitrilases. Appl. Microbiol. Biotechnol. 97, 6603-6611 (2013).

52. Xi, H., Tian, Y., Zhou, N., Zhou, Z. \& Shen, W. Characterization of an N -glycosylated Bacillus subtilis leucine aminopeptidase expressed in Pichia pastoris. J. Basic Microbiol. 55, 236-246 (2015).

53. Setyorini, E., Kim, Y.--., Takenaka, S., Murakami, S. \& Aoki, K. Purification and characterization of a halotolerant intracellular protease fromBacillus subtilis strain FP-133. J. Basic Microbiol. 46, 294-304 (2006).

54. Aziz, R. K. et al. The RAST Server: Rapid Annotations using Subsystems Technology. BMC Genomics 9, 75 (2008).

55. Kishi, L. T., Fernandes, C. C., Omori, W. P., Campanharo, J. C. \& Macedo Lemos, E. Reclassification of the taxonomic status of SEMIA3007 isolated in Mexico B-11A Mex as Rhizobium leguminosarum bv. viceae by bioinformatic tools. BMC Microbiol. 16, 1-8 (2016).

56. Overbeek, R. et al. The SEED and the Rapid Annotation of microbial genomes using Subsystems Technology (RAST). Nucleic Acids Res. 42, D206-D214 (2014).

57. Thompson, J. D., Higgins, D. G. \& Gibson, T. J. CLUSTAL W: improving the sensitivity of progressive multiple sequence alignment through sequence weighting, position-specific gap penalties and weight matrix choice. Nucleic Acids Res. 22, 4673-80 (1994).

58. Ashkenazy, H., Erez, E., Martz, E. \& Pupko, T. \& Ben-Tal, N. ConSurf 2010: Calculating evolutionary conservation in sequence and structure of proteins and nucleic acids. Nucleic Acids Res. 38, 529-533 (2010).

59. Petersen, T. N., Brunak, S., von Heijne, G. \& Nielsen, H. SignalP 4.0: discriminating signal peptides from transmembrane regions. Nat. Methods 8, 785-786 (2011).

60. Fiser, A., Sali, A. \& Šali, A. MODELLER: Generation and Refinement of Homology-Based Protein Structure Models. Methods Enzymol. 374, 461-491 (2003).

61. Odintsov, S. G., Sabała, I., Bourenkov, G., Rybin, V. \& Bochtler, M. Substrate access to the active sites in aminopeptidase T, a representative of a new metallopeptidase clan. J. Mol. Biol. 354, 403-412 (2005).

62. Sabała, G. E., Bourenkov, I. G., Rybin, V. \& Bochtler, M. Staphylococcus aureus aminopeptidase $S$ is a founding member of a new peptidase clan. J. Biol. Chem. 280, 27792-27799 (2005).

63. McGuffin, L. J., Buenavista, M. T. \& Roche, D. B. The ModFOLD4 server for the quality assessment of 3D protein models. Nucleic Acids Res. 41, W368-W372 (2013).

64. Pierce, B. G. et al. Structural bioinformatics ZDOCK server: interactive docking prediction of protein - protein complexes and symmetric multimers. Bioinformatics 30, 1771-1773 (2014).

65. Oliveira, S. H. P. et al. KVFinder: steered identification of protein cavities as a PyMOL plugin. BMC Bioinformatics 15, 197 (2014). 
66. DeLano, W. L. The PyMOL Molecular Graphics System, Version 1.7.4 Schrödinger, LLC (2004).

67. Pereira, M. R., Mercaldi, G. F., Maester, T. C., Balan, A. \& De Macedo Lemos, E. G. Est16, a new esterase isolated from a metagenomic library of a microbial consortium specializing in diesel oil degradation. PLoS One 10, 1-16 (2015).

68. Maester, T. C., Pereira, M. R., Machado Sierra, E. G., Balan, A. \& de Macedo Lemos, E. G. Characterization of EST3: a metagenomederived esterase with suitable properties for biotechnological applications. Appl. Microbiol. Biotechnol. 100, 5815-5827 (2016).

69. Bradford, M. M. A rapid and sensitive method for the quantitation of microgram quantities of protein utilizing the principle of protein-dye binding. Anal. Biochem. 72, 248-254 (1976).

70. Laemmli, U. K. Cleavage of structural proteins during the assembly of the head of bacteriophage T4. Nature 227, 680-5 (1970).

71. Greenfield, N. J. Using circular dichroism collected as a funcion of temperature to determine the thermodynamics of protein unfolding and binding interactions. Nat. Protoc. 1, 2527-2535 (2009).

72. West, L., Yang, D. \& Stephens, C. Use of the Caulobacter crescentus Genome Sequence To Develop a Method for Systematic Genetic Mapping. J. Bacteriol. 184, 2155-2166 (2002).

73. Liu, Z. et al. Efficient Construction of Large Genomic Deletion in Agrobacterium tumefaciens by Combination of Cre/loxP System and Triple Recombineering. Curr. Microbiol. 72, 465-472 (2016).

74. Beringer, J. E. R factor transfer in Rhizobium leguminosarum. J. Gen. Microbiol. 84, 188-98 (1974).

75. Oliveira, N. M. et al. Correction: Biofilm Formation As a Response to Ecological Competition. PloS Biol. 13, e1002232 (2015).

76. Hwang, G. Y., Kuo, L. Y., Tsai, M. R., Yang, S. L. \& Lin, L. L. Histidines 345 and 378 of Bacillus stearotheromophilus leucine aminopeptidase II are essential for the catalytic activity of the enzyme. Antonie van Leeuwenhoek, Int. J. Gen. Mol. Microbiol. 87, 355-359 (2005).

77. Jankiewicz, U. \& Wnuk, a An activated by cobalt alkaline aminopeptidase from Bacillus mycoides. Appl. Biochem. Microbiol. 47, 136-143 (2011).

78. Khan, A. R., Nirasawa, S., Kaneko, S., Shimonishi, T. \& Hayashi, K. Characterization of a solvent resistant and thermostable aminopeptidase from the hyperthermophillic bacterium, Aquifex aeolicus. Enzyme Microb. Technol. 27, 83-88 (2000).

79. Chung, D.-M., Lee, G., Chun, S.-S., Chung, Y. \& Chun, H. Effect of $\mathrm{NaCl}$ on Hydrolytic Activity of Leucine Aminopeptidase from Bacillus sp. N2. J. Life Sci. 21, 761-765 (2011).

80. Lee, G., Chun, S., Kho, Y. \& Chun, H. Purification and properties of an extracellular leucine aminopeptidase from the Bacillus sp. N2. J. Appl. Microbiol. 85, 561-566 (1998).

\section{Acknowledgements}

We would like to thank the Programa de Pós Graduação em Microbiologia Agropecuária, UNESP, Jaboticabal, São Paulo State, Brazil. This work was supported by the Coordenação de Aperfeiçoamento de Pessoal de Nível Superior (CAPES) and the Conselho Nacional de Desenvolvimento Científico e Tecnológico (CNPq).

\section{Author Contributions}

E.M.S., E.G.M.L. and E.R.M. conception and design of the study; E.M.S., M.R., T.M., E.S.G.-P. and E.G.M.L. analysis and interpretation of data; E.M.S., M.R. and T.M. wrote the manuscript; E.G.M.L. conceived and supervised the study and made manuscript revisions.

\section{Additional Information}

Supplementary information accompanies this paper at doi:10.1038/s41598-017-10932-8

Competing Interests: The authors declare that they have no competing interests.

Publisher's note: Springer Nature remains neutral with regard to jurisdictional claims in published maps and institutional affiliations.

(c) (i) Open Access This article is licensed under a Creative Commons Attribution 4.0 International

License, which permits use, sharing, adaptation, distribution and reproduction in any medium or format, as long as you give appropriate credit to the original author(s) and the source, provide a link to the Creative Commons license, and indicate if changes were made. The images or other third party material in this article are included in the article's Creative Commons license, unless indicated otherwise in a credit line to the material. If material is not included in the article's Creative Commons license and your intended use is not permitted by statutory regulation or exceeds the permitted use, you will need to obtain permission directly from the copyright holder. To view a copy of this license, visit http://creativecommons.org/licenses/by/4.0/.

(C) The Author(s) 2017 